\title{
Evaluation of the efficacy of platelet-rich plasma in preventing postoperative intraabdominal adhesions
}

\author{
Ersin Turan ${ }^{1}$ (ID), Barış Ayhan²(ID), Süleyman Kargın³(ID), Osman Doğru4(ID), Nevzat Serdar Uğraş5 (ID) \\ ${ }^{1}$ Clinic of General Surgery, Beyhekim State Hospital, Konya, Turkey \\ ${ }^{2}$ Clinic of General Surgery, Private Akademi Hospital, Konya, Turkey \\ ${ }^{3}$ Department of General Surgery, KTO Karatay University School of Medicine, Konya, Turkey \\ ${ }^{4}$ Clinic of General Surgery, Konya Training and Research Hospital, Konya, Turkey \\ ${ }^{5}$ Department of General Surgery, Selcuk University School of Medicine, Konya, Turkey
}

\section{ABSTRACT}

Objective: Postoperative intraabdominal adhesions still maintain their currency as serious causes of morbidity and mortality. This study aimed at evaluating the role of platelet-rich plasma (PRP) in the prevention of intraabdominal adhesions.

Material and Methods: A total of 16 healthy rabbits were used within the scope of the study. The animals were allocated into two groups as Group 1 (control group) and Group 2 (study group). In all subjects, cecal abrasion was formed by laparotomy. In the study group, platelet rich plasma was administered intraabdominally. At the end of the study, the adhesions were evaluated by Nair's Score.

Results: Total adhesion score in Group 1 was 8, while the mean score was 1. On the other hand, total adhesion score in Group 2 was 12, while the mean score was 1.5. There was no statistical difference between both groups by total adhesion score and mean fibrosis score. However, mean scores for inflammatory cell infiltration and angiogenesis were higher in Group 2 and the differences were statistically significant $(p=0.021)$.

Conclusion: We were not able to report the positive results of PRP; however, we believe that we shed an important light for future studies which might be conducted using the combination of different methods.

Keywords: Platelet-rich plasma, laparotomy, adhesions

Cite this article as: Turan E, Ayhan B, Kargın S, Doğru O, Uğraş NS. Evaluation of the efficacy of platelet-rich plasma in preventing postoperative intraabdominal adhesions. Turk J Surg 2020; 36 (1): 53-58

\section{Corresponding Author}

Süleyman Kargın

E-mail: drs.kargin@hotmail.com

Received: 08.05.2019

Accepted: 06.11.2019

Available Online Date: 18.03 .2020

O Copyright 2020 by Turkish Surgical Society Available online at www.turkjsurg.com

DOI: $10.5578 /$ turkjsurg.4421

\section{INTRODUCTION}

Fibrous bands, which develop between the serosal surfaces of one or more tissues or organs in the ventral cavity, cause postoperative intraabdominal adhesions. Problems like mechanical or functional intestinal obstructions, volvuluses, infertility, and abdominal pain can be seen in time because of these adhesions. Therefore, postoperative intraabdominal adhesions still maintain their currency as serious causes of morbidity and mortality. Patients frequently present to hospitals with recurrent intestinal obstruction and abdominal pain, and they usually have to be admitted to the hospital to be treated. Many studies aiming to prevent adhesions could not reach a final conclusion about the subject $(1,2)$. Although adhesions can be partially prevented through the developments in laparoscopic methods, they still account for one of the most significant postoperative problems for both physicians and patients.

The peritoneum has a structure which can be subjected to re-epithelization rapidly and in a short span of time and which can continuously enable secretion and absorption. This kind of histological structure and physiological function plays an important role in the formation or prevention of intraabdominal adhesions. Accordingly, causes of intraabdominal adhesions and practices about these causes differ from one patient to the other but it is not possible to talk about a standard treatment or measures to be taken to prevent them. In our study, we aimed at preventing adhesions by utilizing growth factor platelet-rich plasma (PRP) whose positive impact on wound healing has been proven (Table 1). We investigated the positive impacts of the factors contained by platelets on adhesions. We formed experimental adhesions using rabbit subjects and evaluated the efficiency of PRP. 
Table 1. The primary growth factors in PRP content

Platelet derived growth factor: Accelerates cellular replication and angiogenesis

Vascular endothelial growth factor: Accelerates angiogenesis

Transforming growth factor group: At least 3 factors are in this group. They play a key role in fibrosis and muscular cell balance

Fibroblast growth factor: Stimulates myoblast proliferation as well as playing a role in angiogenesis

Epidermal growth factor: Modulates epithelial and mesenchymal cell proliferation

Hepatocyte growth factor: Accelerates angiogenesis

Insulin-like growth factor: Mediates muscular growth and repair, myoblast and fibroblast stimulation

The aim of this study was to contribute to the development of standard treatment strategies by investigating the efficiency of PRP in preventing postoperative intraabdominal adhesions.

\section{MATERIAL and METHODS}

Our study was conducted upon the consent of Necmettin Erbakan University Experimental Research and Practice Center's Board of Ethics for Experimental Animals and carried out at the same center (2013-022). A total of 16 healthy rabbits, whose live weights varied between $2.3-3.7 \mathrm{~kg}$, were used within the scope of the study. The rabbits were fed by standard rabbit feed during the adaptation period, 12 hours before the procedures, and during the postoperative period and water was kept ready at all times. The animals were allocated into two groups as Group 1 (control group) and Group 2 (study group). While the study group was given PRP, the control group was not. Each group had eight experimental animals.

\section{PRP Preparation}

Initially, $20 \mathrm{~mL}$ of blood -in the form of $10 \mathrm{~mL} / \mathrm{kg}$ - was drawn in order to obtain PRP from the animals in Group 2. $20 \mathrm{~mL}$ of blood was also drawn from each animal in Group 1 in order not to affect experiment results and enable similar conditions. The blood drawn from Group 1; however, was not subjected to any process. The venous blood drawn from the animals in Group 2 was placed in $10 \mathrm{~mL}$ sterile tubes containing 3.8\% citrate phosphate dextrose adenine. In order to fractionate the drawn venous blood into its components, it was initially centrifuged for 10 minutes at 1000 cycle/minute based on studies about obtaining the right platelet concentration for PRP (1-3). The blood was separated into 3 components through this procedure: at the base was the red blood cells, in the middle was PRP, and at the top was platelet-poor plasma. PRP and poor plasma were placed into a different sterile vacuum tube by a sterile injector for a second centrifuge. The second centrifuge was carried out at 1300 cycle/minute for 10 minutes. While PRP remained at the bottom of the tube, platelet-poor plasma stayed on top. Following the drawing of platelet-poor plasma by a sterile injector, PRP remained at the bottom of the vacuum tube. Studies have shown that 4 times more than the amount of normal platelet concentration was able to be obtained through this method (1-3). Within the scope of our study, $2 \mathrm{~mL}$ of PRP was obtained from each $20 \mathrm{~mL}$ venous blood. PRP was administered to the study group by a sterile injector at a rate of $1 / 6$ by mixing it with $10 \%$ calcium gluconate $(3,4)$.

The animals in both groups were anesthetized by intramuscular injections of $35 \mathrm{mg} / \mathrm{kg}$ Ketamine $\mathrm{HCl}$ (Ketalar; Pfizer, Ortaköy, Istanbul) and $15 \mathrm{mg} / \mathrm{kg}$ Xylazine $2 \% \mathrm{HCl}$ (XylazinBio, Bioveta PLC, Ivanovice na Hane, Czech Republic). The cecum was exposed through laparotomy. Abrasion was performed by a sponge till small bleeds were visible. Following the cecal abrasion, the abdomens of the animals in Group 1 were closed up by continuous 2/0 prolene sutures. The abrasion procedure was done in the same way to the animals in the PRP group and the PRP, which was separately obtained for each animal, was sprayed by a sterile injector on to the abrasion area. The abdomens of the animals in the PRP group were also closed up by continuous 2/0 prolene sutures.

The animals were sacrificed by high doses of anesthesia after 14day follow-up. We entered the abdomens of the animals by a new U-shape incision, which was $2 \mathrm{~cm}$ lateral to the previous incision line. A surgeon blind to the groups graded the adhesions according to Nair's adhesion classification system (Table 2).

Table 2. Nair's adhesion classification system

Grade 0: No adhesions

Grade 1: Single adhesion band between an organ and the peritoneum

Grade2: Two adhesion bands between an organ and the peritoneum

Grade 3: Adhesions between more than one organ and the peritoneum

Grade 4: Organs are adherent to the peritoneum or widespread adhesions 


\section{Pathological Investigation}

The abraded intestinal segments were removed for pathological investigation. $1 \times 1 \mathrm{~cm}$-sized tissues removed from the adhesion areas of the rabbits in both groups were fixed in 10\% buffered formalin for two days. Tissue samples taken from these were buried in paraffin following routine tissue processing procedures. 4-micron sections obtained from paraffin blocks were stained in hematoxylin-eosin to evaluate inflammatory cell infiltration and in Masson's trichrome stain to evaluate fibroblastic activation. The tissues in both groups were analyzed for fibroblastic activation, angiogenesis, and inflammatory cell infiltration by using a light microscope.

\section{Statistical Evaluation}

The evaluation of all statistical data was conducted by SPSS version 15.0. Fibroblastic activation, angiogenesis, and inflammatory cell infiltration scores achieved through histopathological analysis were compared by chi-squared test, while the existence of adhesions in the groups was compared by Fisher's exact chisquare test. Mann-Whitney $U$ test was utilized in the comparison of nonparametric values. Statistical significance for all tests was taken to be $p<0.05$.

\section{RESULTS}

A surgeon blind to the groups graded the adhesions according to Nair's adhesion classification system by laparotomy following the sacrification of animals (Tables 3). While 5 animals had adhesions in Group 1, 6 animals had adhesions in Group 2.

Total adhesion score in Group 1 was 8, while the mean score was 1. On the other hand, total adhesion score in Group 2 was 12, while the mean score was 1.5 (Table 3). Mean score for the PRP group was higher than that of the non-PRP group but the difference between the groups was not statistically significant $(p=0.321)$.
Fibrosis, inflammatory cell infiltration, and angiogenesis were pathologically investigated in the experimental animals (Figure 1, Table 4). Mean fibrosis score in Group 2 was higher than that of Group 1 but there was no statistical significance ( $p=0.065$; Table 5). Further, mean scores for inflammatory cell infiltration and angiogenesis were higher in Group 2 and the differences were statistically significant ( $p=0.021$; Table 5).

\section{DISCUSSION}

It has been reported that mechanical traumas and surgical procedures in abdominal organs and the serosal surfaces of tissues give way to tissue damage and therefore provide the basis for the development of peritoneal adhesions through pulling the cells into these areas by inflammatory exudates (5). In studies conducted for the prevention of the development of intraabdominal adhesions, anti-inflammatory and cytotoxic agents have been used to decrease fibrinous exudation, heparin and oxalates have been used for the inhibition of coagulation, plasminogen stimulants, pepsin, trypcin, streptokinase, and urokinase have been used for the stimulation of fibrinolitic activity and hydroflotation effective agents and drugs like carboxymethyl cellulose, amnion liquid, oil, vaseline, and dextran which enable the mechanical separation of serosal surfaces have also been used (6-12).

The effect of PRP on intraabdominal adhesions is still controversial. The experimental study by Kaya et al. have demonstrated that PRP neither reduces nor exacerbates postoperative adhesions (13). On the other hand, Oz et al. in the experimental study comparing the effect of hyaluronic acid PRP on adhesions has claimed that PRP leads to a significant decrease in adhesion scores (14). We investigated the efficacy of growth factor rich PRP, whose positive impact on wound healing have been proven, on adhesions in our study (Table 1). We also aimed to utilize the positive impacts of PRP, which has been started to be used in

Table 3. Evaluation of the groups'identified adhesions in laparotomy and Nair's score

\begin{tabular}{|c|c|c|c|c|c|}
\hline \multirow[b]{2}{*}{ Animal } & \multicolumn{2}{|c|}{ Control group } & \multicolumn{2}{|c|}{ Study group } & \multirow[t]{2}{*}{$p$} \\
\hline & Nair's Score & Adhesions & Nairs's Score & Adhesions & \\
\hline $1^{\text {st }}$ & 1 & Single adhesion band & 3 & Multiple adhesion bands & \\
\hline $2^{\text {nd }}$ & 2 & Two adhesion bands & 2 & Two adhesion bands & \\
\hline $3^{\text {rd }}$ & 0 & No adhesions & 2 & Two adhesion bands & \\
\hline $4^{\text {th }}$ & 1 & Single adhesion band & 0 & No adhesions & \\
\hline $5^{\text {th }}$ & 0 & No adhesions & 1 & Single adhesion band & \\
\hline $6^{\text {th }}$ & 1 & Single adhesion band & 1 & Single adhesion band & \\
\hline $7^{\text {th }}$ & 3 & Multiple adhesion bands & 0 & No adhesions & \\
\hline $8^{\text {th }}$ & 0 & No adhesions & 3 & Multiple adhesion bands & \\
\hline Total score/mean score & $8 / 1$ & & $12 / 1.5$ & & 0.321 \\
\hline
\end{tabular}



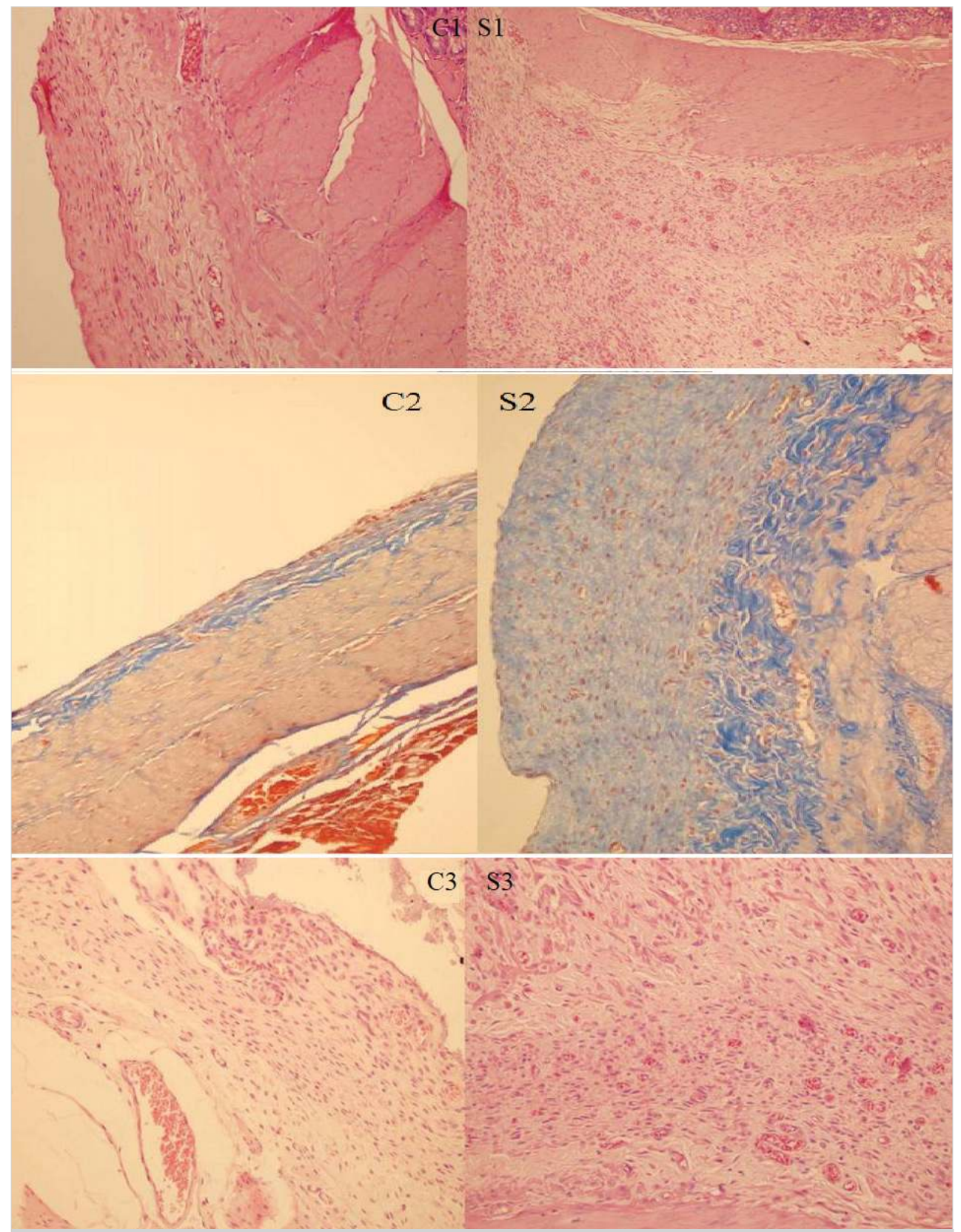

Figure 1. Pathological examination of the samples taken that fibrosis (C1 and S1, Hematoxylin-Eosin, original magnification, 200x), inflammatory cell infiltration (C2 and S2, Masson's Trichrome, original magnification, 200x), and angiogenesis (C3 and S3, Hematoxylin-Eosin, original magnification, 200x) in groups. C: Control group; S: Study group.

such fields as dentistry, orthopedics, plastic surgery, and burn treatment, on wound healing although it causes an increase in fibroblast activity $(1,3,4)$.

Anitua et al. described pure platelet-rich plasma in 1999 for the first time (2). He took out the part over the buffy coat, which remained between the serum at the top and the decayed part at the bottom, by centrifuging the venous blood in citrated tubes. This part is the one containing the most platelets. The first use of platelet concentrations, however, began in 1997 with Whitman $\mathrm{DH}$ et al.'s oral and maxillofacial surgical procedures (15). We formed experimental adhesions on rabbit subjects and evaluated the efficacy of PRP. While the mean Nair's Score for the nonPRP group in our study was 1, it was 1.5 for the PRP group. The difference between the groups was not statistically significant $(p=0.321)$ and it was not possible to state that PRP had a positive impact on the prevention of adhesions. Pathological analyses of 
Table 4. Pathological evaluation of the groups

\begin{tabular}{|l|c|c|c|c|c|c|}
\hline & \multicolumn{3}{|c|}{ Group 1 } & \multicolumn{2}{c|}{ Group 2 } \\
\hline Subject & Fibrosis & Inflammation & Angiogenesis & Fibrosis & Inflammation & Angiogenesis \\
\hline Subject1 & ++ & - & + & ++ & +++ & ++ \\
\hline Subject2 & ++ & + & + & + & + & + \\
\hline Subject3 & - & - & + & - & - & + \\
\hline Subject4 & + & + & - & + & + \\
\hline Subject5 & - & - & + & + & + & + \\
\hline Subject6 & + & + & ++ & - & + \\
\hline Subject7 & ++ & + & - & ++ & + \\
\hline Subject8 & - & - & & & + \\
\hline
\end{tabular}

Table 5. Comparison of the subjects without adhesion and with adhesion as pathological data

\begin{tabular}{|l|c|c|c|c|}
\hline \multicolumn{2}{|c|}{} & Fibrosis Total/Mean score & Inflammation Total/Mean score & Angiogenesis Total/Mean score \\
\hline \multirow{3}{*}{ Subject without adhesion } & Group 1 (8 subjects) & $8 / 1$ & $4 / 0.5$ & $6 / 0.75$ \\
\cline { 2 - 5 } & Group 2 8 subjects) & $10 / 1.25$ & $9 / 1.1$ & $12 / 1.5$ \\
\hline Subject with adhesion & Group 1 (5 subjects) & $8 / 1.6$ & $4 / 0.8$ & $6 / 1.2$ \\
\cline { 2 - 5 } & Group 2 (6 subjects) & $10 / 1.6$ & $9 / 1.5$ & $12 / 2$ \\
\hline p & 0.065 & 0.165 & $\mathbf{0 . 0 2 1}$ \\
\hline \multicolumn{2}{|l}{ In calculation of those scores every + in table 4 are equal to 1 point. }
\end{tabular}

the groups revealed that the fibrosis score of the PRP group was higher than that of the non-PRP group but the difference was not statistically significant either $(p=0.065)$. It was ascertained that inflammatory cell infiltration and angiogenesis were increased by PRP, which was statistically significant $(p=0.021)$. It might be argued that PRP might have given way to an increase in postoperative intraabdominal adhesions through its impact on the increase in fibroblast activity. The results of our study did not reveal a significant increase in adhesions but it can also be put forward that PRP, which had positive effects on wound healing, increased fibrosis as well although no statistically significant result was obtained. We attempted to utilize the factors contained by platelets in order to rapidly eliminate tissue damage on the serosal surface due to mechanical trauma. Although we aimed at preventing adhesions through the impact of these factors, we were not able to achieve a statistically significant result.

Koc et al. have investigated the effects of methylprednisolone and dimethyl sulphoxide on the prevention of intraabdominal adhesions in rabbits and obtained positive results with anti- inflammatory effect (5). Anti-inflammatory effect; however, can have a negative impact on the normal wound healing process besides adhesions. Thus, one can question the safety of an anastomosis performed in this way. Yeo et al. have utilized hyaluronic acid hydrogels in order to prevent postoperative intraabdom- inal adhesions and achieved positive results (16). One cannot argue for a standard treatment although many similar studies have concluded that adhesions are experimentally prevented.

\section{CONCLUSION}

We were not able to report the positive results of our PRP use in neither macroscopic nor pathological ways but we believe that we shed an important light for future studies which might be conducted using the combination of different methods.

Ethics Committee Approval: Our study was conducted upon the consent of Necmettin Erbakan University Experimental Research and Practice Center's Board of Ethics for Experimental Animals and carried out at the same center (2013-022).

Informed Consent: This research was not need any informed consent for experimental study.

Peer-review: Externally peer-reviewed.

Author Contributions: Concept - B.A., E.T.; Design - O.D., B.A.; Supervision O.D.; Resource - E.T., B.A., S.K.; Materials - B.A., S.K., S.U.; Data Collection and/ or Processing - E.T., B.A., S.K.; Analysis and/or Interpretation - S.K.; Literature Search - E.T.; Writing Manuscript - S.K., O.D.; Critical Reviews - O.D.

Conflict of Interest: All authors declare no conflict of interest and financial relationships.

Financial Disclosure: The authors declared that this study has received no financial support. 


\section{REFERENCES}

1. Pallua N, Wolter T, Markowicz M. Platelet rich plasma in burns. Burns 2010;36:4-8. [CrossRef]

2. Anitua E. Plasma rich in growth factors: preliminary results of use in the preparation of future sites for implants. Int J Oral Maxillofac Implants 1999;14:529-35. [CrossRef]

3. Maciel FB, DeRossi R, Modolo TJ, Pagliosa RC, Leal CR, Delben AA. Scannin electron microscopy and microbiological evaluation of equine burn wound repair platelet rich plasma gel treatment. Burns 2012;38(7):1058-65. [CrossRef]

4. Karalezli N. What is PRP? Necmettin Erbakan University Meram Medical Faculty Journal of News and Publicity 2013;16-8. [CrossRef]

5. Koc Y, Celik I, Erol M, Aydin MF. Researching the effects of methylprednisolone and dimethyl sulphoxide (D1S0) on the prevention of peritoncal adhesions in rabbits. Eurasian J Vet Sci 2007;21:73-9. [CrossRef]

6. Liakakos T, Thomakos N, Fine PM, Dervenis C, Young RL. Peritoneal adhesions: etiology, pathophysiology and clinical significance. Recent advances in prevention and management. Dig Surg 2001;18:260-73. [CrossRef]

7. Yilmazlar T, Kaya E, Gurpinar E, Emiroglu H. Efficiacy of tenoxicam on intraabdominal adhesion prevention in a rat model. J Int Med Res 1996;24:352-7. [CrossRef]

8. Yalin R. Adhesions and prevention after intra-abdominal surgeries. Turk J Colorectal Dis 1997;7:12-7. [CrossRef]
9. Southwood LL, Baxter GM, Hutchison JM, Shuster R. Survey ol diplomtes of the american coolage of veterinary surgeons regarding postoperative intraabdominal adhesion formation in horses undergoing abdominal surgery. JAVMA 1997;21:1573-6. [CrossRef]

10. Dijkstra FR, Nieuwenhuijzen M, Reijnen MM, van Goor H. Recent clinical developments in pathophysiology, epidemiology, diagnosis and treatment of intraabdominal adhesions. Scand J Gastroenterol 2000;232:52-9. [CrossRef]

11. Durmus AS, Han MC. Effect of bovine amniotic fluid on intraabdominal adhesions. Indian Vet J 2006;83:621-3. [CrossRef]

12. Koc Y, Alkan F, Erol M. An experimental study evaluating the effect of sodium carboxymethylcellulose on the prevention of postoperative intraabdominal adhesions. Revue Med Vet 2002;153:803-80. [CrossRef]

13. Kaya F, Kismet K, Ozer H, Soylu VG, Duymus ME, Akgun YA, et al. Can platelet-rich plasma be used safely in intra-abdominal operations? Bratis/ Lek Listy 2016;117:525-9. [CrossRef]

14. Oz M, Cetinkaya N, Bas S, Korkmaz E, Ozgu E, Terzioglu GS. A randomized controlled experimental study of the efficacy of platelet-rich plasma and hyaluronic acid for the prevention of adhesion formation in a rat uterine horn model. Arch Gynecol Obstet 2016;294:533-40. [CrossRef]

15. Whitman DH, Berry RL, Green DM. Platelet gel: an autologous alternative to fibrin glue with applications in oral and maxillofacial surgery. J Oral Maxillofac Surg 1997;55(11):1294-9. [CrossRef]

16. Yeo Y, Highley CB, Bellas E, Ito T, Marini R, Kohane DS. In situ cross-linkable hyaluronic acid hydrogels prevent post-operative abdominal adhesions in a rabbit model. Biomaterials 2006;27(27):4698-705. [CrossRef]

\title{
ORIJIINAL ÇALIŞMA-ÖZET
}

Turk J Surg 2020; 36 (1): 53-58

\section{Postoperatif intraabdominal adezyonları önlemede trombositten zengin plazmanın etkinliğinin değerlendirilmesi}

\author{
Ersin Turan ${ }^{1}$, Barış Ayhan ${ }^{2}$, Süleyman Kargın ${ }^{3}$, Osman Doğrư ${ }^{4}$, Nevzat Serdar Uğraş ${ }^{5}$ \\ ${ }^{1}$ Beyhekim Devlet Hastanesi, Genel Cerrahi Kliniği, Konya, Türkiye \\ ${ }^{2}$ Özel Akademi Hastanesi, Genel Cerrahi Kliniği, Konya, Türkiye \\ ${ }^{3}$ KTO Karatay Üniversitesi Tıp Fakültesi, Genel Cerrahi Anabilim Dalı, Konya, Türkiye \\ ${ }^{4}$ Konya Eğitim ve Araştırma Hastanesi, Genel Cerrahi Kliniği, Konya, Türkiye \\ ${ }^{5}$ Selçuk Üniversitesi Tıp Fakültesi, Genel Cerrahi Anabilim Dalı, Konya, Türkiye
}

\section{ÖZET}

Giriş ve Amaç: Postoperatif intraabdominal adezyonlar, günümüzde hala ciddi morbidite ve mortalite nedenidir. Bu çalışmada, trombositten zengin plazma (PRP)'nın intraabdominal adezyonların önlenmesindeki rolünün değerlendirilmesi amaçlanmıştır.

Gereç ve Yöntem: Çalışma kapsamında toplam 16 sağlıklı tavşan kullanıldı. Hayvanlar, Grup 1 (kontrol grubu) ve Grup 2 (çalışma grubu) olarak iki gruba ayrıldı. Tüm deneklerde laparotomi ile çekal abrazyon oluşturuldu. Çalışma grubunda PRP intraabdominal olarak uygulandı. Çalışmanın sonunda adezyonlar Nair's Skoru ile değerlendirildi.

Bulgular: Grup 1'deki toplam adezyon skoru 8 iken, ortalama skor 1 idi. Öte yandan, Grup 2'deki toplam adezyon skoru 12 iken, ortalama skor 1,5 idi. Her iki grup arasında toplam adezyon skoru ve ortalama fibroz skoru açısından istatistiksel olarak bir fark yoktu. Ancak, enflamatuvar hücre enfiltrasyonu ve anjiyogenez skorları Grup 2'de istatistiksel olarak daha yüksekti $(p=0,021)$.

Sonuç: PRP'nin postoperatif intraabdominal adezyonları önlemesine dair olumlu sonuçları bulamadık. Ancak, farklı yöntemlerin kombinasyonu kullanılarak yapılabilecek gelecekteki çalışmalar için bu çalışmanın önemli bir ışık tutacağına inanıyoruz.

Anahtar Kelimeler: Trombositten zengin plazma, laparotomi, adezyon

Doi: $10.5578 /$ turkjsurg.4421 